\title{
First report of a 'Candidatus Phytoplasma phoenicium'-related strain (16SrIX-C) associated with phyllody disease of Reseda lutea
}

\author{
Mohammad Salehi $^{1}$ (D) $\cdot$ Mohammad Mehdi Faghihi ${ }^{1} \cdot$ Nazanin Ebadi $^{1} \cdot$ Elham Salehi $^{1}$
}

Received: 3 September 2021 / Accepted: 31 October 2021 / Published online: 10 November 2021

(c) Australasian Plant Pathology Society Inc. 2021

\begin{abstract}
During a survey in 2019, Reseda lutea plants showing phyllody symptoms were observed in Fars province, Iran. Presence of phytoplasma in the symptomatic plants was confirmed by PCR amplifications of $16 S r R N A$ and $r p$ genes. Sequence analysis revealed that the phytoplasma associated with the phyllody affected plants belongs to subgroup 16SrIX-C of 'Candidatus Phytoplasma phoenicium' species. This is the first report of a 16SrIX-C phytoplasma strain associated with phyllody symptoms of Reseda lutea in Iran and probably in the world.
\end{abstract}

Keywords PCR $\cdot R p$ gene $\cdot$ Virtual RFLP $\cdot$ Yellow mignonette $\cdot 16 S$ rRNA gene

Reseda lutea (Family: Resedaceae) known as yellow mignonette or wild mignonette is a perennial plant that grows widely in arid and semi-arid rangeland in Iran (Moghaddam 1977). R. lutea has been used as a medicinal plant and in the carpet and rug industry as a source of natural dye (Abdallah and De Witt 1967). In Iran, it is mainly used in animal husbandry as a grazing plant (Moghaddam 1977). Reseda lutea has been reported as a harmful weed in field crops (Bailey and Wicks 1995) and a potential host of Watermelon mosaic virus (Amiri and Ebrahim-Nesbat 1977) in Iran.

During a survey in April 2019, R. lutea phyllody (RLPh) disease was observed in Shiraz, Fasa, Darab and Firuzabad areas (Fars province, Iran). The main disease symptoms were flower virescence, phyllody, proliferation, little leaf and shortened internodes (Fig. 1). Disease incidence rate in certain patches of $R$. lutea was up to $15 \%$. Phyllody affected and symptomless $R$. lutea plants were sampled from Golestan town (Shiraz area). Total DNA was extracted from $0.3 \mathrm{~g}$ of flower tissue from six symptomatic and six symptomless plants using the small-scale procedure of Zhang et al. (1998) as modified by Abou-Jawdah et al. (2002). PCR amplifications of $16 S r R N A$ and $r p$ genes was used to confirm the presence of phytoplasma in the symptomatic plants.

Mohammad Salehi

Plant Protection Research Department, Fars Agricultural and Natural Resources Research and Education Center, AREEO, Zarghan, Iran
The amplification of ribosomal DNA was done by nested PCR using primers pairs P1/P7 (Deng and Hiruki 1991; Schneider et al. 1995) and R16F2n/R16R2 (Gundersen and Lee 1996). A 1:30 dilution of PCR products amplified by primer pair P1/P7 was used as a template for the second round of PCR with primer pair R16F2n/R16R2. Primer pair R16F2n/R16R2 amplifies about 1250 bp of the phytoplasma $16 \mathrm{~S} r R N A$ gene. Additionally, $\mathrm{rpF} 1 / \mathrm{rpR} 1$ (Lim and Sears 1992) primer pair was used in direct PCR to amplify approximately $1250 \mathrm{bp}$ of the ribosomal protein $(r p)$ gene. PCR was performed in $50 \mu \mathrm{l}$ reaction mixture containing $100 \mathrm{ng}$ DNA, $0.4 \mu \mathrm{M}$ of each primer, $0.2 \mathrm{mM}$ of dNTP mix, $1.25 \mathrm{U}$ Taq DNA polymerase (CinnaGen, Tehran, Iran) and 1X PCR buffer. The reactions were denatured at $95^{\circ} \mathrm{C}$ for $120 \mathrm{~s}$, followed by 35 cycles of $95^{\circ} \mathrm{C}$ for $60 \mathrm{~s}, 55^{\circ} \mathrm{C}\left(42{ }^{\circ} \mathrm{C}\right.$ for rp amplification) for $60 \mathrm{~s}$ and $72{ }^{\circ} \mathrm{C}$ for $180 \mathrm{~s}$, with a final extension of $72{ }^{\circ} \mathrm{C}$ for $10 \mathrm{~min}$.

Amplicons of 1250 and $1256 \mathrm{bp}$, respectively, corresponding to $\mathrm{R} 16 \mathrm{~F} 2 \mathrm{n} / \mathrm{R} 16 \mathrm{R} 2$ and $\mathrm{rpF} 1 / \mathrm{rpR} 1$ primer pairs were yielded only in symptomatic plants. Amplicons were ligated onto pTZ57R/T vector and cloned into Escherichia coli $\mathrm{DH} 5 \alpha$ cells using InsT/A Clone ${ }^{\mathrm{TM}}$ PCR Product Cloning Kit (Metabion, Germany) according to manufacturer's instructions. Presence of the correct insert was confirmed by restriction endonuclease analysis using EcoRI and Pst enzymes. Plasmid DNAs from recombinant colonies were purified using GF-1 PCR Clean-Up Kit (Vivantis, Malysia, HQ) and the cloned $\mathrm{R} 16 \mathrm{~F} 2 \mathrm{n} / \mathrm{R} 16 \mathrm{R} 2$ and $\mathrm{rpF} 1 / \mathrm{rpR} 1$ fragments 
Fig. 1 Symptoms of Reseda lutea phyllody disease: a, a symptomless plant; $b$, flower phyllody, virescence and proliferation in a phyllody affected plant; c, comparison of phyllody affected (left) and healthy (right) branches of Reseda lutea plant
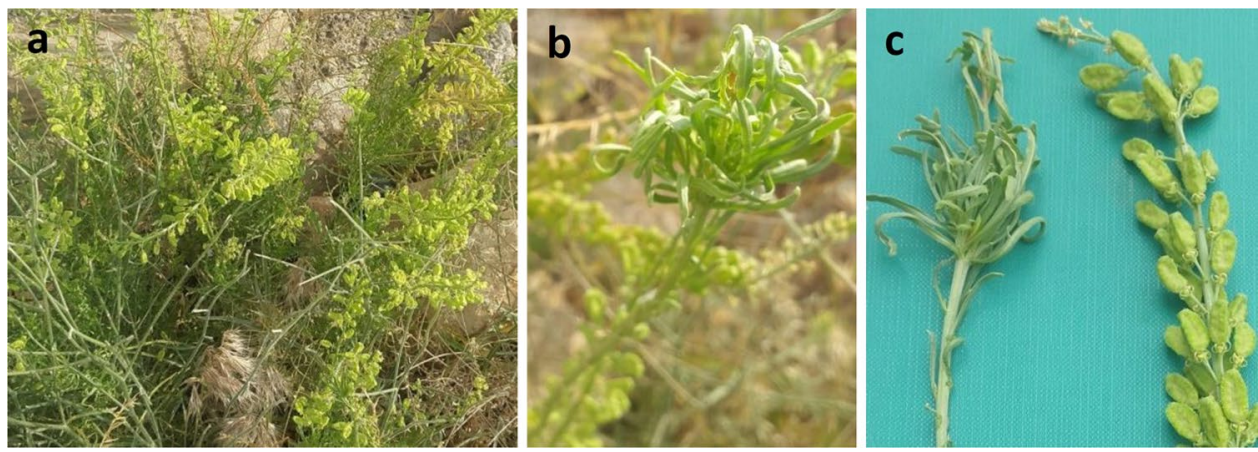

were sequenced on both strands by a commercial DNA sequencing service (Macrogen, South Korea). M13 forward and reverse primers were used as sequencing primers. Each of the R16F2n/R16R2 and rpF1/rpR1 primed sequences from six phyllody affected $R$. lutea showed $100 \%$ sequence identity and the consensus sequences were submitted to GenBank with the accession numbers MZ536389 and MZ542534, respectively. BLASTn searches using obtained sequences showed that RLPh phytoplasma strain had $100 \%$ sequence identity with Knautia arvensis strains (accession Nos. EF186823 and EF186801, respectively), representatives of 16SrIXC subgroup phytoplasmas ('Candidatus Phytoplasma phoenicium'-related) (Lee et al. 2012). Phylogenetic trees constructed with $16 S$ rRNA (Fig. 2) and $r p$ (Fig. 3) genes sequences showed that RLPh phytoplasma is classified in the 16SrIX group, subgroup C.

The 16SrIX-C subgroup phytoplasma strains have been previously detected in almond (Salehi et al. 2006), eggplant (Tohidi et al. 2015), tomato (Jamshidi et al. 2014), hemp (Rasoulpour et al. 2017), grapevine (Salehi et al. 2016; Ghayeb Zamharir et al. 2017) and sesame (Salehi et al. 2017) in Iran. Considering that 16SrIX-C phytoplasma strains can be vectored by Circulifer haematoceps (Salehi et al. 2017), a highly polyphagous insect feeding on a variety of herbaceous plants (EFSA 2015), R. lutea may act as a reservoir plant host for transmission of these strains to above mentioned plant species.
Fig. 2 Phylogenetic tree based on partial 16S rDNA sequences constructed by the neighborjoining method showing relationship among Reseda lutea phyllody phytoplasma (rectangular) and reference phytoplasmas from GenBank. Acholeplasma laidlawii was used as an outgroup to root the tree. Numbers at the nodes are bootstrap (confidence) values based on 1000 repetitions. The scale bars indicates 0.07 substitution per nucleotide position

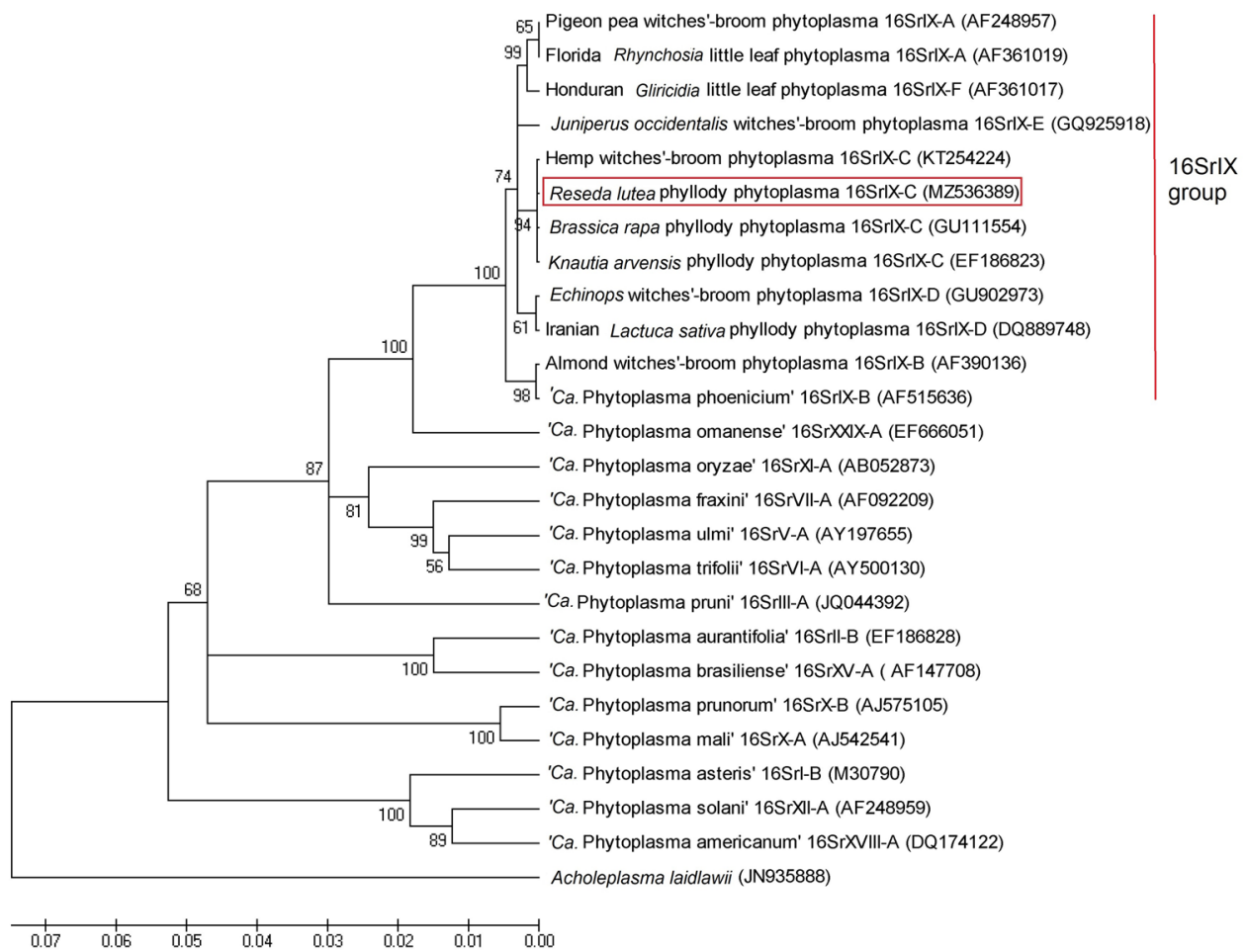


Fig. 3 Phylogenetic tree based on partial sequences of $r p$ gene constructed by the neighbor-joining method showing relationship between Reseda lutea phyllody phytoplasma (rectangular) and reference phytoplasmas from GenBank. Acholeplasma laidlawi was used as an outgroup to root the tree. Numbers at the nodes are bootstrap (confidence) values based on 1000 repetitions. The scale bars indicates 0.5 substitution per nucleotide position

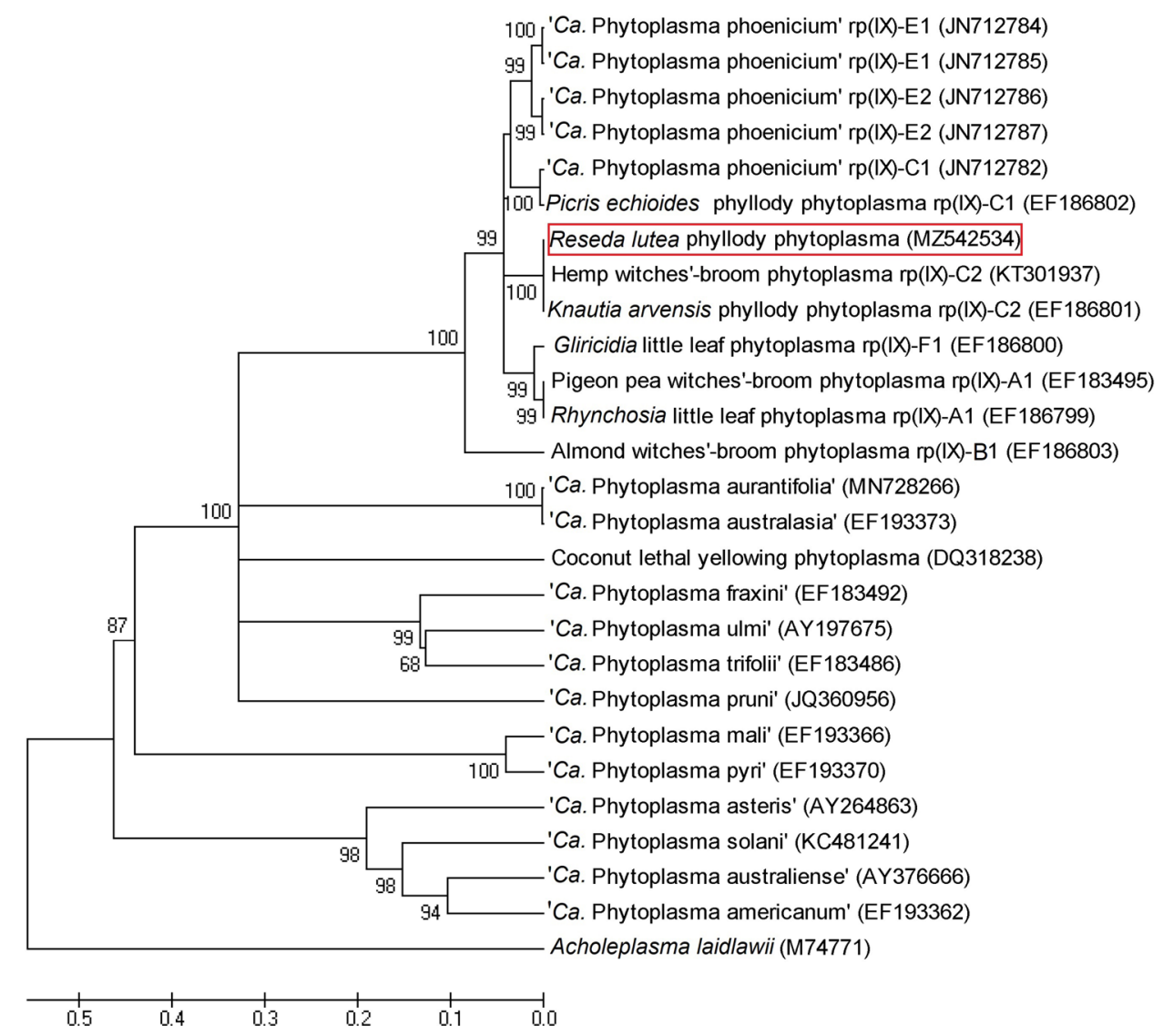

To our knowledge, this is the first report of the 16SrIXC subgroup phytoplasma associated with $R$. lutea in Iran and probably worldwide.

Acknowledgements This study was supported byIranian Agricultural Research, Education and Extension Organization (AREEO) (Project number 4-100-100000-118501-85002).

\section{Declarations}

Conflict of Interest Statement The authors declare that there is no conflict of interest.

\section{References}

Abdallah MS, De Witt HCD (1967) The Resedaceae - A Taxonomical Revision of the Family. Mededelingen Landbouwhogeschool Wageningen. (Veenman H. and Zonen N. V., Wageningen)

Abou-Jawdah Y, Karakashina A, Sobh H, Martini M, Lee I-M (2002) An epidemic of almond witches'-broom in Lebanon: Classification and phylogenetic relationships of associated phytoplasma. Plant Dis 86:477-484

Amiri J, Ebrahim-Nesbat F (1977) Reseda lutea L. and Fumaria asepala Boiss. the natural hosts of Watermelon mosaic virus in the Mashed Areas. Iran J Plant Pathol 13:51-52
Bailey PT, Wicks TJ (1995) Biological control of Reseda lutea L. (Resedaceae), a weed of cereal crops in South Australia. Thirteenth Int. Plant Protection Cong., The Hague, 2-7 July 1995, Abstract No. 1410. Eur J Plant Pathol Supplement

Deng S, Hiruki C (1991) Amplification of 16S rRNA genes from culturable and nonculturable Mollicutes. J Microbiol Methods 14:53-61

EFSA PLH Panel (EFSA Panel on Plant Health) (2015) Scientific Opinion on pest categorisation of Circulifer haematoceps and C. tenellus. EFSA J 13(1):3988,32pp. https://doi.org/10.2903/j.efsa. 2015.3988

Ghayeb Zamharir M, Paltrinieri S, Hajivand S, Taheri M, Bertaccini A (2017) Molecular identification of diverse 'Candidatus Phytoplasma'species associated with grapevine decline in Iran. J Phytopathol 165:407-413

Gundersen DE, Lee IM (1996) Ultrasensitive detection of phytoplasmas by nested-PCR assays using two universal primer pairs. Phytopathol Mediterr 35(3):144-151

Jamshidi E, Jafarpour B, Rouhani H, Salehi M (2014) Association of members of clover proliferation (16SrVI) and pigeon pea witches'- broom (16SrIX) phytoplasma groups with tomato big bud disease in Iran. Iran J Plant Pathol 50:77-89

Lee IM, Botner-Parker KD, Zhao Y, Bertaccini A, Davis RE (2012) Differentiation and classification of phytoplasmas in the pigeon pea witches'-broom group (16SrIX): An update based on multiple gene sequence analysis. Int J Syst Evol Microbiol 62:2279-2285

Lim P-O, Sears BB (1992) Evolutionary relationships of a plant pathogenic mycoplasmalike organism and Acholeplasma laidlawii deduced from two ribosomal protein gene sequences. J Bacteriol 174:2606-2611 
Moghaddam MR (1977) Reseda lutea: Multipurpose Plant for Arid and Semiarid Lands. J Range Manage 30:71-72

Rasoulpour R, Salehi M, Bertaccini A (2017) Detection and partial characterization of a 16SrIX-C phytoplasma associated with hemp witches'-broom in Iran. J Plant Pathol 99:219-223

Salehi E, Salehi M, Taghavi SM, Izadpanah K (2016) First report of a 16SrIX group (pigeon pea witches'-broom) phytoplasma associated with grapevine yellows in Iran. J Plant Pathol 98:367

Salehi M, Esmailzadeh-Hosseini S, Salehi E, Bertaccini A (2017) Genetic diversity and vector transmission of phytoplasmas associated with sesame phyllody in Iran. Folia Microbiol 62:99-109

Salehi M, Izadpanah K, Heydarnejad J (2006) Characterization of a new almond witches'- broom phytoplasma in Iran. J Phytopathol $154: 386-391$
Schneider B, Seemüller E, Smart C, Kirkpatrick C (1995) Phylogenetic classification of plant pathogenic mycoplasmalike organisms or phytoplasmas. In: Razin R, Tully JG (eds) Molecular and Diagnostic Procedures in Mycoplasmology. Academic Press, San Diego, USA, pp 369-380

Tohidi Z, Salehi M, Ghasemi S, Khanchezar A, Shahamiri SM (2015) Association of a 16SrIX-C phytoplasma with eggplant phyllody in Iran. J Crop Prot 4:247-256

Zhang YP, Uyemoto JK, Kirkpartick BC (1998) A small-scale procedure for extracting nucleic acid from woody plants infected with various phytoplasma for PCR assay. J Virol Meth 71:95-100 